\title{
Reprocessing semicritical items: Outbreaks and current issues
}

\author{
William A. Rutala PhD, MPH, CIC ${ }^{a, *}$, David J. Weber MD, MPH ${ }^{\mathrm{a}, \mathrm{b}}$ \\ ${ }^{a}$ Hospital Epidemiology, University of North Carolina Health Care, Chapel Hill, NC \\ ${ }^{\mathrm{b}}$ Division of Infectious Diseases, University of North Carolina School of Medicine, Chapel Hill, NC
}

Key Words:

\section{Endoscopes}

Disinfection

Sterilization

Medical Devices

\begin{abstract}
Semicritical medical devices are defined as items that come into contact with mucous membranes or nonintact skin (eg, gastrointestinal endoscopes, endocavitary probes). Such medical devices require minimally high-level disinfection. As many of these items are temperature sensitive, low-temperature chemical methods must be used rather than steam sterilization. Strict adherence to current guidelines is required as more outbreaks have been linked to inadequately cleaned or disinfected endoscopes and other semicritical items than any other reusable medical devices.
\end{abstract}

In the United States in 2010, there were approximately 51.4 million inpatient surgical procedures and an even larger number of invasive medical procedures performed. ${ }^{1}$ For example, there were over 6.9 million upper gastrointestinal (GI), 11.5 million lower GI, and 228,000 biliary endoscopies performed in $2009 .^{2}$ Each of these procedures involves contact by a medical device or surgical instrument with a patient's sterile tissue or mucous membranes. A major risk of all such procedures is the introduction of pathogenic microbes, which can lead to infection. Failure to properly disinfect or sterilize equipment may lead to transmission via contaminated medical and surgical devices (eg, carbapenem-resistant Enterobacteriaceae [CRE]).,

Multiple studies in many countries have documented lack of compliance with established guidelines for disinfection and sterilization. ${ }^{5}$ Failure to comply with scientifically-based guidelines has led to numerous outbreaks and patient exposures. ${ }^{6}$ In fact, nearly all infections and patient exposures associated with reprocessing medical or surgical instruments involve high-level disinfection (HLD) of reusable semicritical items. ${ }^{6-8}$ Because of noncompliance with recommended reprocessing procedures, the Centers for Disease Control and Prevention (CDC) and the Food and Drug Administration (FDA) issued a health advisory alerting health care providers and facilities about the public health need to properly maintain, clean, disinfect, and sterilize reusable medical devices in September $2015 .^{9}$ In this expanded and updated version of a previous article on this subject, ${ }^{10,11}$ we will

\footnotetext{
* Address correspondence to William A. Rutala, PhD, MPH, CIC, Division of Infectious Diseases, University of North Carolina School of Medicine, Bioinformatics Building, CB\#7030, Chapel Hill, NC 27514-7030.

E-mail address: brutala@med.unc.edu (W.A. Rutala).

Conflicts of interest: Dr. Rutala is a consultant for Advanced Sterilization Products. Dr. Weber is a consultant for Germitec.
}

examine outbreaks associated with semicritical items and current issues associated with reprocessing semicritical items. Because semicritical items carry the greatest risk of infection we also will discuss reprocessing semicritical items such as: GI endoscopes and bronchoscopes, nasal endoscopes, endocavitary probes, transrectal ultrasound-guided prostate biopsy probes, tonometers, laryngoscopes, transesophageal echocardiogram (TEE) probes, infrared coagulation devices, and urologic instruments (eg, cystoscopies, ureteroscopes).

\section{A RATIONAL APPROACH TO DISINFECTION AND STERILIZATION}

Approximately 50 years ago, Earle H. Spaulding ${ }^{12}$ devised a rational approach to disinfection and sterilization of patient-care items or equipment. This classification scheme is so clear and logical that it has been retained, refined, and successfully used by infection control professionals and others when planning methods for disinfection or sterilization. ${ }^{13-18}$ Spaulding believed that the nature of disinfection could be understood more readily if instruments and items for patient care were divided into 3 categories, based on the degree of risk of infection involved in the use of the items. The 3 categories he described were critical (enters sterile tissue and must be sterile), semicritical (contacts mucous membranes and requires HLD), and noncritical (contact with intact skin and requires low-level disinfection). Although the scheme remains valid there are some examples of disinfection studies with viruses, mycobacteria, and protozoa that challenge the current definitions and expectations of high- and low-level disinfection. ${ }^{19}$

\section{SEMICRITICAL ITEMS}

Semicritical items are those that come in contact with mucous membranes or nonintact skin. Respiratory therapy and anesthesia 
Table 1

Summary of advantages and disadvantages of chemical agents used as chemical sterilants or as high-level disinfectant/chemical sterilant*

\begin{tabular}{|c|c|c|}
\hline Sterilization method & Advantages & Disadvantages \\
\hline $\begin{array}{l}\text { Peracetic acid/hydrogen } \\
\text { peroxide }\end{array}$ & - No activation required & $\begin{array}{l}\text { - Material compatibility concerns (lead, brass, copper, zinc) } \\
\text { both cosmetic and functional } \\
\text { - Limited clinical experience } \\
\text { - Mucous membrane and respiratory health effects } \\
\text { - Potential for eye and skin damage }\end{array}$ \\
\hline Glutaraldehyde & $\begin{array}{l}\text { - Numerous use studies published } \\
\text { - Relatively inexpensive } \\
\text { - Excellent material compatibility }\end{array}$ & $\begin{array}{l}\text { - Respiratory irritation from glutaraldehyde vapor } \\
\text { - Pungent and irritating odor } \\
\text { - Relatively slow mycobactericidal activity (unless other dis- } \\
\text { infectants added such as phenolic, alcohol) } \\
\text { - Coagulates blood and fixes tissue to surfaces } \\
\text { - Allergic contact dermatitis } \\
\text { - ACGIH recommends limiting employee exposure to ceiling } \\
\text { concentration of } 0.05 \text { ppm }\end{array}$ \\
\hline $\begin{array}{l}\text { Hydrogen peroxide } \\
\text { (standard) }\end{array}$ & $\begin{array}{l}\text { - No activation required } \\
\text { - May enhance removal of organic matter and organisms } \\
\text { - No disposal issues } \\
\text { - No odor or irritation issues } \\
\text { - Does not coagulate blood or fix tissues to surfaces } \\
\text { - Inactivates Cryptosporidium at } 6 \%-7.5 \% \\
\text { - Use studies published }\end{array}$ & $\begin{array}{l}\text { - Material compatibility concerns (brass, zinc, copper, and } \\
\text { nickel/silver plating) both cosmetic and functional } \\
\text { - Serious eye damage with contact }\end{array}$ \\
\hline OPA & $\begin{array}{l}\text { - Fast acting high-level disinfectant } \\
\text { - No activation required } \\
\text { - Odor not significant } \\
\text { - Excellent materials compatibility claimed } \\
\text { - Does not coagulate blood or fix tissues to surfaces claimed } \\
\text { - Relatively rapid mycobactericidal activity }\end{array}$ & $\begin{array}{l}\text { - Stains protein gray (eg, skin, mucous membranes, clothing, } \\
\text { and environmental surfaces) } \\
\text { - More expensive than glutaraldehyde } \\
\text { - Eye irritation with contact } \\
\text { - Slow sporicidal activity } \\
\text { - Anaphylactic reactions to OPA in bladder cancer patients } \\
\text { with repeated exposure to OPA through cystoscopy }\end{array}$ \\
\hline Peracetic acid & $\begin{array}{l}\text { - Standardized cycle (eg, liquid chemical sterilant processing system } \\
\text { using peracetic acid, rinsed with extensively treated potable water) } \\
\text { - Low temperature }\left(50^{\circ} \mathrm{C}-55^{\circ} \mathrm{C} \text { ) liquid immersion sterilization }\right. \\
\left.\text { - Environmental friendly by-products (acetic acid, } \mathrm{O}_{2}, \mathrm{H}_{2} \mathrm{O}\right) \\
\text { - Fully automated } \\
\text { - Single-use system eliminates need for concentration testing } \\
\text { - May enhance removal of organic material and endotoxin } \\
\text { - No adverse health effects to operators under normal operating con- } \\
\text { ditions } \\
\text { - Compatible with many materials and instruments } \\
\text { - Does not coagulate blood or fix tissues to surfaces } \\
\text { - Sterilant flows through scope facilitating salt, protein, and microbe } \\
\text { removal } \\
\text { - Rapidly sporicidal } \\
\text { - Provides procedure standardization (constant dilution, perfusion of } \\
\text { channel, temperatures, exposure) }\end{array}$ & $\begin{array}{l}\text { - Potential material incompatibility (eg, aluminum anodized } \\
\text { coating becomes dull) } \\
\text { - Used for immersible instruments only } \\
\text { - Biological indicator may not be suitable for routine } \\
\text { monitoring } \\
\text { - One scope or a small number of instruments can be } \\
\text { processed in a cycle } \\
\text { - More expensive (endoscope repairs, operating costs, } \\
\text { purchase costs) than HLD } \\
\text { - Serious eye and skin damage (concentrated solution) with } \\
\text { contact } \\
\text { - Point-of-use system, no sterile storage } \\
\text { - An AER using } 0.2 \% \text { peracetic acid not FDA-cleared as } \\
\text { sterilization process but HLD }\end{array}$ \\
\hline $\begin{array}{l}\text { Improved hydrogen per- } \\
\text { oxide ( } 2.0 \%) \text {; high- } \\
\text { level disinfectant }\end{array}$ & $\begin{array}{l}\text { - No activation required } \\
\text { - No odor } \\
\text { - Nonstaining } \\
\text { - No special venting requirements } \\
\text { - Manual or automated applications } \\
\text { - } 12 \text { month shelf life, } 14 \text { day reuse } \\
\text { - } 8 \text { min at } 20^{\circ} \mathrm{C} \text { high-level disinfectant claim }\end{array}$ & $\begin{array}{l}\text { - Material compatibility concerns because of limited clinical } \\
\text { experience } \\
\text { - Organic material resistance concerns because of limited data }\end{array}$ \\
\hline
\end{tabular}

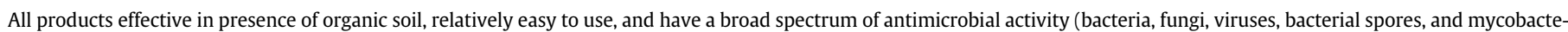

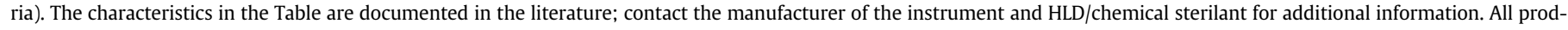
ucts listed in the Table are FDA-cleared as chemical sterilants except OPA and 2\% accelerated hydrogen peroxide, which are FDA-cleared high-level disinfectants.

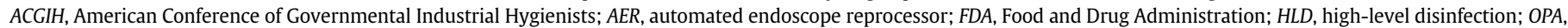
ortho-phthalaldehyde.

*Modified from Rutala and Weber ${ }^{10,11,13-17}$

equipment, GI endoscopes, bronchoscopes, laryngoscopes, TEE probes, tonometers, endocavitary probes, transrectal ultrasound-guided prostate biopsy probes, ${ }^{20}$ cystoscopes, hysteroscopes, infrared coagulation devices, and diaphragm fitting rings are included in this category. These medical devices should be free of all microorganisms (ie, mycobacteria, fungi, viruses, and bacteria), although small numbers of bacterial spores may be present. Intact mucous membranes, such as those of the lungs or the GI tract, generally are resistant to infection by common bacterial spores but susceptible to other organisms such as bacteria, mycobacteria, and viruses. Semicritical items minimally require HLD using chemical disinfectants. Glutaraldehyde, hydrogen peroxide, orthophthalaldehyde (OPA), peracetic acid, peracetic acid with hydrogen peroxide, and a chlorine-based system are cleared by the FDA ${ }^{21}$ and are dependable high-level disinfectants provided the factors influencing germicidal procedures are met. Table 1 lists the FDA-cleared high-level disinfectants and chemical sterilants with the advantages and disadvantages of each. The exposure time for most high-level disinfectants varies from $8-45$ minutes at $20^{\circ} \mathrm{C}-25^{\circ} \mathrm{C} .{ }^{21}$ As with all medications and devices, users must be familiar with the manufacturer's instructions for use (IFU). When a disinfectant is selected for use with certain patientcare items, the chemical compatibility after extended use with the items to be disinfected also must be considered. Disinfection strategies for some semicritical items (eg, applanation tonometers, rectal/vaginal probes) are highly variable. ${ }^{22}$ 
Because semicritical equipment has been associated with reprocessing errors that result in patient look-back and patient notifications, it is essential that control measures be instituted to prevent patient exposures. $^{6}$ Before new equipment (especially semicritical equipment as the margin of safety is less than that for sterilization $)^{23}$ is used for patient care on more than 1 patient, reprocessing procedures for that equipment should be developed. The FDA requests that the device manufacturer include at least 1 validated cleaning and disinfection and sterilization protocol in the labeling for their device. Staff should receive training on the safe use and reprocessing of the equipment and be competency tested. At the University of North Carolina Hospitals, to ensure patient-safe instruments, all staff that reprocess semicritical instruments (eg, instruments that contact a mucous membrane such as vaginal probes, endoscopes, prostate probes) are required to attend a 3-hour class on HLD of semicritical instruments initially and a 1-hour refresher class annually. The 3-hour class includes the rationale for and importance of HLD, discussion of highlevel disinfectants and exposure times, reprocessing steps, monitoring minimum effective concentration, personal protective equipment, and the reprocessing environment (establish "dirty-to-clean" flow). Infection control rounds or audits should be conducted at least annually in all clinical areas that reprocess critical and semicritical devices to ensure adherence to the reprocessing guidelines, manufacturers' instructions-for-use, and institutional policies. This includes reprocessing critical and semicritical medical and surgical instruments in outpatient care facilities as many patient exposures and infections have occurred in this setting. ${ }^{24}$ Results of infection control rounds should be provided to the unit managers and deficiencies in reprocessing should be corrected and the corrective measures documented to infection control within 30 days. Patient safety issues such as the wrong contact time, temperature, or concentration of high-level disinfectant require immediate correction.

Semicritical items that will have contact with mucous membranes of the GI tract or upper respiratory tract should be rinsed with sterile water or filtered water or tap water followed by an alcohol rinse. ${ }^{17,25}$ An alcohol rinse and forced-air drying markedly reduces the likelihood of contamination of the instrument (eg, endoscope), most likely by removing the wet environment favorable for bacterial growth. ${ }^{26}$ After rinsing, items should be dried and stored in a manner that protects them from damage or contamination. Drying also retards biofilm formation. ${ }^{27}$ There is no recommendation to use sterile or filtered water rather than tap water for rinsing semicritical equipment that will have contact with the mucous membranes of the rectum (eg, rectal probes, anoscope) or vagina (eg, vaginal probes). ${ }^{17}$

Semicritical items represent the greatest risk of disease transmission as far more health care-associated infections have been caused by reusable semicritical items than critical or noncritical items. ${ }^{11}$ There is virtually no documented risk of transmitting infectious agents to patients via noncritical items ${ }^{28}$ when they are used as noncritical items and do not contact nonintact skin and/or mucous membranes. Similarly, critical items are rarely ${ }^{29}$ associated with disease transmission. In contrast, semicritical items (eg, GI endoscopes), by virtue of the body cavities they enter, may contain $10^{7-10}\left(7-10-\log _{10}\right)$ enteric microorganisms. ${ }^{30,31}$ Investigations have demonstrated that the cleaning step in endoscope reprocessing results in a $2-6-\log _{10}$ reduction of microbes and the HLD step results in another $4-6-\log _{10}$ reduction of mycobacteria for a total $6-12-\log _{10}$ reduction of microbes. $^{30-32}$ Thus, the margin of safety associated with cleaning and HLD of GI endoscopes is minimal or nonexistent (level of contamination: 4- $\log _{10}$ [maximum contamination, minimal cleaning/HLD] to $-5-\log _{10}$ [minimum contamination, maximum cleaning/HLD]). ${ }^{23}$ Therefore, any deviation from proper reprocessing (such as crevices associated with the elevator channel) could lead to failure to eliminate contamination with a possibility of subsequent patient-topatient transmission. This low (or nonexistent) margin of safety
Table 2

Infections and outbreaks associated with semicritical medical devices*

\begin{tabular}{lll}
\hline Instruments & $\begin{array}{l}\text { \# Outbreaks/ } \\
\text { Infections }\end{array}$ & $\begin{array}{l}\text { \# Outbreaks/ } \\
\text { Infections with } \\
\text { bloodborne pathogens }\end{array}$ \\
\hline $\begin{array}{ll}\text { Vaginal probes } \\
\text { Nasal endoscopes }\end{array}$ & $0^{* *}$ & 0 \\
Hysteroscopes & 0 & 0 \\
Laryngoscopes & 0 & 0 \\
Urologic instrumentation & $2^{43-45}$ & 0 \\
$\quad 8^{46-53}$ & 0 \\
$\quad$ eg, cystoscopes, ureteroscopes) & $1^{40}$ & 0 \\
$\quad$ guided prostate probes & $5^{51,54-57}$ & 0 \\
$\begin{array}{l}\text { Transesophageal echocardiogram } \\
\text { Applanation tonometers }\end{array}$ & $2^{41,42}$ & $3 \mathrm{HBV}^{34} ; \mathrm{HCV}^{35,36}$ \\
GI endoscopes/bronchoscopes & $\sim 130^{7,8}$ & \\
\hline
\end{tabular}

$G I$, gastrointestinal; $H B V$, hepatitis B virus; $H C V$, hepatitis $C$ virus.

*These infections/outbreaks were found in the peer-review literature through PubMed and Google.

**Does not include outbreaks associated with contaminated ultrasound gel used with vaginal probes or transmission via health care personnel.

associated with endoscope reprocessing compares to the $17-\log _{10}$ margin of safety associated with cleaning and sterilization of surgical instruments. $^{23}$ This is the reason that semicritical items represent the greatest risk of disease transmission via a reusable medical or surgical instrument and critical items are rarely ${ }^{29}$ associated with infection.

\section{OUTBREAKS}

Transmission of infections (and bloodborne pathogens) associated with the use of semicritical medical devices

GI endoscopes and bronchoscopes have been associated with far more outbreaks of infections ( $>130$ outbreaks) than any other reusable medical or surgical device in health care. ${ }^{7,8}$ Other semicritical items (eg, urologic instruments, TEE probes) have also been associated with outbreaks of infection. To assess the frequency of infections/outbreaks associated with all semicritical medical devices (Table 2), a systematic review of the literature was conducted. ${ }^{33}$ The databases used were PubMed and Google and the search terms and subject heading terms were: hepatitis, hepatitis B virus (HBV), hepatitis $C$ virus (HCV), human immunodeficiency virus (HIV), endoscopes, medical devices, semicritical medical items, vaginal probes, nasal endoscopes, hysteroscopes, urologic instruments, GI endoscopes, bronchoscopes, transrectal-ultrasound guided prostate probe, applanation tonometers, TEE, infrared coagulation, infection, and outbreaks. The reference lists of articles retrieved were also searched for relevant articles. There was no language restriction; articles were evaluated for inclusion when an English translation of the article or abstract was available. Abstracts from scientific meetings were not included.

HCV and HBV transmission during endoscopy and use of semicritical medical devices can occur, but it is rare. Three reports related to breaches in semicritical device reprocessing were found involving HBV and HCV, and all involved GI endoscopes. ${ }^{34-36}$ There is 1 report of HBV transmission via GI endoscopy ${ }^{34}$ and 2 reports of HCV transmission associated with GI endoscopes. ${ }^{35,36}$ In general, transmission of HBV and HCV in health care in the United States is uncommon and typically associated with unsafe injection practices. ${ }^{37}$ No articles relating to possible transmission of HIV via medical instruments, including semicritical medical devices, were identified. The articles for HBV and HCV transmission associated with GI endoscopes were written prior to the comprehensive endoscope reprocessing guidelines that are now available. 
There are limitations to this type of review. For example, only published literature was included, and it is more likely that instances of transmission were published than instances of nontransmission. This would likely overestimate the frequency of transmission. In contrast, many outbreaks go undetected and almost certainly outbreaks associated with semicritical medical devices have gone unreported. For example, most persons with incident HCV and HBV infections are asymptomatic. Even when symptomatic persons are identified, many hospitals and health departments do not have the resources to thoroughly investigate all individuals with HBV or $\mathrm{HCV}^{38}{ }^{38}$ We have the greatest risk of transmission associated with GI endoscopes and bronchoscopes owing to the high microbial load in GI endoscopes $\left(10^{7}-10^{10}\right.$ in internal channels of a GI endoscope) and complexity of the instrument. The microbial load associated with a vaginal probe, nasal endoscopes, and cystoscopes is thought to be less owing to the presence of fewer organisms at those sites (eg, vagina, oropharynx $\left[10^{1}-10^{5} / \mathrm{mL}\right.$ in nasal washings], urinary tract) compared to the GI tract $\left(10^{9}-10^{12} / \mathrm{mL}\right.$ in the colon). Additionally, endoscopic instruments with channels may allow the development of biofilms when the instruments are not completely dry. ${ }^{23,27}$ For these reasons, there are over 130 reported outbreaks of infections associated with GI endoscopes and bronchoscopes. Many of these outbreaks were related to breeches in endoscope reprocessing (eg, inadequate cleaning, disinfection, and drying procedures) but between 2012 and spring 2015, closed-channel duodenoscopes were linked to at least 25 different outbreaks of multidrug-resistant organisms (MDROs) that sickened at least 250 patients worldwide. ${ }^{8}$ Since 2010, there have been at least 9 outbreaks of duodenoscoperelated infections of MDROs without reprocessing breaches. In these outbreaks, the CDC and/or other investigators monitored endoscope reprocessing procedures and concluded they were compliant with the manufacturer's IFU and professional organizational recommendations. ${ }^{39}$

Transmission of bloodborne pathogens (BBP) (ie, HBV, HCV, HIV) or other infectious agents related to improper reprocessing of a vaginal probe have not been documented. In addition, there are no outbreaks of BBP, or other infections related to lapses in reprocessing of nasal endoscopes and hysteroscopes. Outbreaks associated with the use of vaginal probes have occurred but they have involved the use of a contaminated ultrasound gel or noncompliance with the manufacturer's IFU. ${ }^{33}$ There has been 1 outbreak associated with the transrectal-ultrasound guided prostate probe, ${ }^{40} 2$ outbreaks associated with applanation tonometers. ${ }^{41,42}$ and at least 2 outbreaks connected to laryngoscopes. ${ }^{43-45}$

Eight outbreaks that involved urologic instruments and reprocessing failures were identified. None of those outbreaks involved transmission of BBP such as HIV, HBV and HCV. ${ }^{46-53}$ The lapses in reprocessing included: inadequate camera head cleaning; ${ }^{47}$ improper cleaning and disinfecting cystoscopes for $>10$ years; ${ }^{49}$ incomplete cleaning and disinfection of the cystoscope; ${ }^{48}$ and incorrect cystoscope reprocessing. ${ }^{46}$

Transmission of BBP related to improper reprocessing of a TEE probe has not been documented; however, 5 outbreaks of infection have occurred associated with the use of TEE probes. ${ }^{51,54-57}$ The outbreaks were associated with a damaged or defective probe; ${ }^{54,55}$ noncompliance with reprocessing procedure; ${ }^{56}$ and the use of a TEE probe rinsed with contaminated water. ${ }^{57}$ Outbreaks associated with contaminated ultrasound gel in multiuse bottles used for TEE and other endocavitary probe procedures are not included as they do not represent failure of disinfection, but rather intrinsic or extrinsic contamination of the gel. Recommendations for minimizing the health risks of using gels involve use of single-use, sterile gels for invasive procedures that pass through a tissue, for all studies involving neonates, for all procedures involving sterile equipment or nonintact skin, and for procedures on intact mucous membranes. ${ }^{58}$
A look-back or exposure investigation of patients potentially exposed to $B B P$ via medical instruments

When there is a failure to follow reprocessing guidelines for semicritical items, health care facilities should assess the risk of exposed patients to BBP using a 14-step protocol. ${ }^{6}$ On occasion, health care facilities have considered evaluating exposed patients for not only for BBP but also for other epidemiologically important pathogens such as multidrug resistant Enterobacteriaceae or $C$ difficile. Regarding an epidemiologic look-back investigation (ie, systematic notification of patients by health care facilities) for transmission of other pathogens, we are not aware of any health care facility that conducted an epidemiologic look-back study of improperly reprocessed semicritical medical devices (such as endoscopes) that assessed other pathogens such as multidrug resistant Enterobacteriaceae or $C$ difficile. Largescale epidemiologic look-back investigations of improperly reprocessed semicritical instruments (ie, GI endoscopes) for transmission of BBPs have been conducted. ${ }^{6,59,60}$ In 1 investigation involving endoscopes in a nonhospital endoscopy clinic's endoscope reprocessing failures were not associated with an increased risk of BBP among individuals tested. ${ }^{59}$ In another study involving almost 10,000 persons tested for BBPs, the investigation revealed that exposure to improperly reprocessed ear-nose-throat endoscopes did not result in viral transmission in those patients who had genetic analysis performed. Any potential transmission of BBP from colonoscopy remains unknown because case/proximate patient testing could not be performed. $^{60}$

In addition, some health care facilities have considered evaluating medical charts for evidence of risks or transmission of infection among a certain population. The weakness of such an evaluation is the absence of comparator data. That is, let us say you recognize noncompliance with reprocessing urologic instruments and you look for $E$ coli in patients undergoing cystoscopies in an outpatient urology office. Certainly, you will find a percentage (eg, 10\%) of patients undergoing cystoscopy with $E$ coli in the urinary tract. Unfortunately, you do not have a control population to compare your E coli frequency in the urology clinic. The control population could be a group of persons that underwent cystoscopies in an outpatient urology clinic that reprocessed the endoscope in complete compliance with the professional organization guidelines and manufacturer's IFU. Additionally, to compare the numbers between the 2 outpatient urology clinics, the facilities would have to use the same surveillance methodology, and identify methods to risk adjust the population studied as there are many risk factors for $E$ coli in the urine such as older age, female sex, urinary catheterization, enlarged prostate, diabetes, not receiving antibiotics, malnutrition, et cetera. Therefore, the question you must consider before beginning a chart review is how the data will help you make a decision as you will likely find persons with any outcome you consider (eg, HCV prevalence in US population is $1.3 \%, \mathrm{HBV}$ is $0.4 \%$, and $\mathrm{HIV}$ is $0.3 \%$ ). If you decide to do a chart review, you will need to consider the surveillance method, the outcome indicator to monitor, the time period for observation and benchmarking, and comparator data. Of course, a chart review would be unlikely to completely identify all persons infected (eg, HCV) or colonized (eg, E coli in the urine) because testing asymptomatic patients for colonization or infection is rarely indicated. Active surveillance for such patients would be both logistically difficult and expensive.

\section{REPROCESSING SEMICRITICAL ITEMS}

\section{Reprocessing of GI endoscopes and bronchoscopes}

More health care-associated outbreaks (>130 outbreaks) and patient exposures have been linked to contaminated GI endoscopes 
and bronchoscopes than to any other reusable medical device. ${ }^{7,8}$ Because the risk of transmission via GI endoscopes and bronchoscopes will be reviewed in another article in this journal, ${ }^{61}$ the reason for reprocessing failure will only be briefly discussed. There are at least 2 (and probably 3 ) reasons for this reprocessing failure and why outbreaks continue to occur. ${ }^{23}$ First, studies have shown that the internal channel of GI endoscopes, including duodenoscopes, may contain $10^{7-10}\left(7-10-\log _{10}\right)$ enteric microorganisms. ${ }^{30,31}$ Investigations have demonstrated that the cleaning step in endoscope reprocessing results in a 2-6- $\log _{10}$ reduction of microbes and the HLD step results in another $4-6-\log _{10}$ reduction of mycobacteria for a total $6-12-\log _{10}$ reduction of microbes. ${ }^{30-32}$ Thus, the margin of safety associated with cleaning and HLD of GI endoscopes is minimal or nonexistent (level of contamination: $4-\log _{10}$ or 10,000 microbes [maximum contamination, minimal cleaning/HLD] to $-5-\log _{10}$ [minimum contamination, maximum cleaning/HLD]). Therefore, any deviation from proper reprocessing (such as crevices that harbor microorganisms associated with the elevator channel) could lead to failure to eliminate contamination with a possibility of subsequent patient-to-patient transmission. This low (or nonexistent) margin of safety associated with endoscope reprocessing compares to the $17-\log _{10}$ margin of safety associated with cleaning and sterilization of surgical instruments. ${ }^{23}$

Second, GI endoscopes not only have heavy microbial contamination $\left(10^{7}-10^{10}\right.$ bacteria) but they are complex with long, narrow channels; right angle turns; and difficult to clean and disinfect components (eg, elevator channel). The elevator channel in duodenoscopes is unique to side-viewing endoscopes. It has a separate channel and provides orientation of catheters, guide-wires and accessories into the endoscopic visual field. ${ }^{23}$ This channel is complex in design and has crevices that are difficult to access with a cleaning brush and may impede effective reprocessing. ${ }^{62}$ Based on this and other recent studies, it is likely that MDROs are acting as a "marker" or "indicator" organism for ineffective reprocessing of the complex design of duodenoscopes, which is an infectious risk to patients.

Third, biofilms could impact endoscope reprocessing failure and continued endoscope-related outbreaks. ${ }^{63}$ Biofilms are multilayered bacteria plus exopolysaccharides that cements cells to surfaces. They develop in a wet environment. If reprocessing is performed promptly after use and the endoscope is dry the opportunity for biofilm formation is minimal. ${ }^{64,65}$ However, the formation of endoscopic biofilm during clinical practice may be related to reuse of reprocessing methods such as reuse of detergent, manual cleaning, and incomplete drying. ${ }^{66}$ Ideally, reprocessing should be initiated within 1 hour of use; however, there are no evidence-based guidelines on delayed endoscope reprocessing. ${ }^{67}$ It is unclear, but possible, that biofilms contribute to failure of endoscope reprocessing.

Infection preventionists should ensure that institutional policies are consistent with national guidelines ${ }^{17,25}$ and manufacturers' instructions-for-use, and conduct infection control rounds periodically (eg, at least annually) in areas where endoscopes and other semicritical items are reprocessed to make certain there is compliance with policy. Based on the infection data and risks, the transition to sterilization of duodenoscopes was recommended by an FDA Panel in May 2015. Technologies to allow this change to occur are being developed $^{68}$ and FDA-cleared and should be used when acceptable in terms of sterilization performance, scope performance (for disposable scopes), cost, throughput, and compatibility of materials (eg, adhesives) to sterilization technology. Device and sterilization manufacturers, regulatory agencies, GI physicians, inpatient and outpatient endoscope reprocessing centers as well as professional organizations must reach a general agreement regarding the need for sterilization and the willingness to replace existing disinfection technologies. This transition will occur when we put "the needs of the patient first" and offer every patient an endoscope that is sterile, and thus, devoid of potential pathogens. ${ }^{39}$

\section{Nasal endoscopy}

There are several types of scopes that are used to examine the nose and throat (eg, nasopharyngoscope, rhinolaryngoscopes). Because they become contaminated during use, there is a risk of transmission of infection between patients. Flexible nasopharyngoscopy is a valuable tool enabling easy visualization of the upper aerodigestive tract. In the United States, 3 techniques are available to reprocess nasopharyngoscopes: manual HLD; use of an automated endoscope reprocessor; and use of a disposable sheath with low-level disinfection. ${ }^{17,68-70}$ However, because sheaths/condoms/covers may have tears or breaks that compromise their integrity there was hesitation to allow the use of a sheath to alter the recommendation of HLD. There are now 2 peer-reviewed publications that validate the integrity of the sheath with nasopharyngoscopes along with lowlevel disinfection. ${ }^{71,72}$

One study showed that the use of a high quality, snugly fitting, sterile, disposable polyurethane sheath on nasopharyngoscopes during a clinical examination, combined with enzymatic detergent cleaning and disinfection with $70 \%$ ethanol, provided a reliably decontaminated, patient-ready instrument, which eliminated the need for HLD of nasopharyngoscopes. ${ }^{71}$ Another study found that the contamination rate on nasopharyngolaryngoscope (NPL) with the sheath alone was similar to the contamination rate with the high-level disinfected scope. The authors concluded that using the individually packaged, disposable, sterile sheath on an NPL prevented microbes from adhering to the shaft of the scope, thus providing a safe method of avoiding the transmission of infection from 1 patient to the next patient when using an NPL successively in multiple patients in an otolaryngology clinic. ${ }^{72}$ These 2 studies corroborate the integrity of the sterile polyurethane sheaths used with nasopharyngoscopes, this practice (use of a high-quality, snugly fitting, sterile, disposable sheath on a nasopharyngoscope during a clinical examination, combined with enzymatic detergent cleaning and disinfection with $70 \%$ ethanol) can provide a reliably decontaminated, patientready instrument and may be an option to HLD. Thus, we believe that with this specific sheath and this device (ie, nasopharyngoscope), this practice of using this sheath plus cleaning plus alcohol may be an option to HLD.

\section{Applanation tonometers}

Applanation tonometers are a possible vector for the transmission of infectious disease and outbreaks of epidemic keratoconjunctivitis (caused by adenovirus), ${ }^{41,42}$ and have been related to incompletely disinfected tonometers. ${ }^{22,41,42}$ In view of the potential for transmission of viruses (eg, herpes simplex virus, adenovirus type 8 , or HIV) ${ }^{73}$ by tonometer tips, the $\mathrm{CDC}$ recommended ${ }^{74}$ that the tonometer tips be wiped clean and disinfected for 5-10 minutes with either 3\% hydrogen peroxide, 5,000 ppm chlorine, 70\% ethyl alcohol, or 70\% isopropyl alcohol. However, data suggest that $3 \%$ hydrogen peroxide and $70 \%$ isopropyl alcohol are not effective against adenovirus capable of causing epidemic keratoconjunctivitis and similar viruses and should not be used for disinfecting applanation tonometers. ${ }^{75-77}$ For this reason, the $\mathrm{CDC}$ guideline now recommends to wipe clean tonometer tips and then disinfect them by immersing for 5-10 minutes in either 5,000 ppm chlorine or $70 \%$ ethyl alcohol. ${ }^{17,74-77}$ Structural damage to Schiotz tonometers has been observed with a 1:10 sodium hypochlorite (5,000 ppm chlorine) and $3 \%$ hydrogen peroxide. ${ }^{78}$ After disinfection, the tonometer should be thoroughly rinsed in tap water and airdried before use. We believe that wiping the tonometer tips with a $70 \%$ isopropyl alcohol wipe is insufficient to prevent patient-topatient transmission considering that 2 reports have found that disinfection of pneumotonometer tips between uses with a 70\% isopropyl 
alcohol wipe contributed to outbreaks of epidemic keratoconjunctivitis caused by adenovirus type $8 .^{79,80}$

Of course, intraocular instruments must be cleaned and sterilized between patients. Eye instruments are very delicate and require special handling to prevent damage. Recommended practices are derived from evidence-based recommendations for cleaning and sterilizing all surgical instruments in general, from outbreaks of toxic anterior segment syndrome, and from manufacturers' IFU. ${ }^{81}$ Toxic anterior segment syndrome is an acute severe inflammatory reaction of the anterior chamber of the eye to a toxic contaminant (eg, detergent residues) introduced into the anterior chamber during intraocular surgery. ${ }^{81}$

\section{Endocavitary probes (vaginal probes)}

Vaginal probes are used in sonographic scanning. A vaginal probe and all endocavitary probes without a probe cover are semicritical devices as they have direct contact with mucous membranes (eg, vagina, rectum, and pharynx). Although one could argue that the use of the probe cover changes the category, the CDC guideline for disinfection and sterilization ${ }^{17}$ proposes that a new condom/probe cover should be used to cover the probe for each patient and because condoms/probe covers may fail, ${ }^{82-86}$ HLD of the probe also should be performed. ${ }^{17,87}$ The relevance of this recommendation is reinforced with the findings that sterile transvaginal ultrasound probe covers have a very high rate of perforations even before use $(0 \%, 25 \%$, and $65 \%$ perforations from 3 suppliers) ${ }^{85}$ After oocyte retrieval use, Hignett and Claman ${ }^{85}$ found a very high rate of perforations in used endovaginal probe covers from 2 suppliers (75\% and $81 \%$ ), whereas Amis et al $^{88}$ and Milki and Fisch ${ }^{82}$ demonstrated a lower rate of perforations after use of condoms ( $0.9 \%$ and $2.0 \%$, respectively). Rooks et $\mathrm{al}^{89}$ found that condoms were superior to commercially available probe covers for covering the ultrasound probe $(1.7 \%$ for condoms vs 8.3\% leakage for probe covers). These studies underscore the need for HLD of endocavitary probes between examinations. Although most ultrasound manufacturers have recommend the use of $2 \%$ glutaraldehyde for HLD of contaminated transvaginal transducers, the use of this agent has been questioned ${ }^{90}$ because it may shorten the life of the transducer and may have toxic effects on the gametes and embryos. $^{91}$ Another probe disinfection method that uses a UV-C chamber has been evaluated and is used in Europe and Canada but is not yet FDA-cleared for use in the United States. ${ }^{86,92}$

HLD with an FDA-cleared high-level disinfectant (eg, accelerated hydrogen peroxide) that is nontoxic to staff, patients, probes, and retrieved cells should be used until the effectiveness of alternative procedures against microbes of importance at the cavitary site is demonstrated by well-designed experimental scientific studies. Other probes such as rectal and cryosurgical probes/devices should also be subjected to HLD between patients.

Cryosurgery is the use of freezing temperatures to elicit a specific response in tissue (eg, inflammatory response with minor freezing). Some cryosurgical probes (eg, used in prostate cancer) are not fully immersible. When reprocessing these probes, the tip of the probe should be immersed in a high-level disinfectant for the appropriate time (eg, 20 minutes exposure with $2 \%$ glutaraldehyde) and any other portion of the probe that could have mucous membrane contact should be disinfected by immersion or wrapping with a cloth soaked in a high-level disinfectant to allow the recommended contact time. After disinfection, the probe should be rinsed with tap water and dried before use. Health care facilities that use nonimmersible probes should replace them as soon as possible with fully immersible probes.

As with other HLD procedures, proper cleaning of probes is necessary to ensure the success of the subsequent disinfection. ${ }^{93}$ Muradali et $\mathrm{al}^{94}$ demonstrated a reduction of vegetative bacteria inoculated on vaginal ultrasound probes when the probes were cleaned with a towel. No information is available on either the level of contamination of such probes by potential viral pathogens, such as HBV and human papillomavirus (HPV), ${ }^{95}$ or their removal by cleaning (such as with a towel). Because these pathogens may be present in vaginal and rectal secretions and contaminate probes during use, HLD of the probes after such use is recommended.

Concerning low-level disinfection of vaginal probes, M'Zali et $\mathrm{al}^{96}$ demonstrated the persistence of microbial contamination on transvaginal ultrasound probes after low-level disinfection with a quaternary ammonium compound and chlorhexidine gluconate. Meyers et $\mathrm{al}^{97}$ demonstrated that some high-level disinfectants (eg, glutaraldehyde, OPA) may not be effective against HPV but this requires corroboration. At the present time, we do not believe that this report should result in an alteration of current cleaning/disinfection recommendations.

The CDC guideline for disinfection and sterilization states that even if probe covers have been used, clean and high-level disinfect the semicritical devices such as rectal probes, vaginal probes, and cryosurgical probes with a product that is not toxic to staff, patients, probes, and retrieved germ cells (if applicable). Use a high-level disinfectant at the FDA-cleared exposure time unless scientific studies and guidelines recommend an alternative time and temperature (eg, glutaraldehyde at 20 minutes, $\left.20^{\circ} \mathrm{C}\right) .{ }^{17,25}$ When probe covers are available, use a probe cover or condom to reduce the level of microbial contamination. Do not use a lower category of disinfection (eg, low-level disinfection) or cease to follow the appropriate disinfectant recommendations when using probe covers because these sheaths and condoms may fail (see exception for nasopharyngoscopes and one tested sheath described earlier). After HLD, rinse all items.

\section{Ultrasound transducer disinfection for assessment and insert of peripheral and central catheters}

At present, there is no consistency in the practice of cleaning/disinfecting ultrasound probes used for the assessment and insertion of peripheral and central catheters. ${ }^{98}$ This begs the question: do ultrasound transducers used for placing peripheral or central venous access devices require HLD or sterilization? A recent publication has interpreted the CDC and the American Institute for Ultrasound in Medicine guidelines to recommend that the probe used for ultrasound-guided central venous catheter insertion be either sterilized or HLD and used with a sterile sheath and sterile gel. ${ }^{98}$ The same article recommended that the probe used to scan across unhealthy skin should be high-level disinfected and used with a clean sheath and clean gel. ${ }^{98}$ The American Institute for Ultrasound in Medicine and Association of Vascular Access guidelines are similar and recommend that all transducers used for peripheral or central venous access device insertion should undergo, at a minimum, low-level disinfection (ie, step 1-clean, step 2-low-level disinfect) and be used in conjunction with a single-use sterile probe cover. ${ }^{99,100}$ Should such a probe on occasion become contaminated with blood or other potentially infectious material, appropriate cleaning and low-level disinfection would eliminate the key BBPs (ie, HIV, HBV, and HCV).

\section{Transrectal ultrasound-guided prostate biopsy probes}

Transrectal ultrasound-guided prostate biopsies are among the most common outpatient diagnostic procedures performed in urology practice, to evaluate patients for prostate cancer after an elevated prostate-specific antigen level or abnormal digital rectal examination findings. ${ }^{40}$ It involves obtaining multiple prostate tissue cores by passing a disposable biopsy needle through a needle guide under ultrasound guidance. All prostatic biopsy procedures result in contamination of the probe with blood or feces. During this procedure, 
the transducer assembly is generally covered with a barrier sheath. ${ }^{101}$ Breaches in the reprocessing of prostate biopsy probes can pose a risk of disease transmission. ${ }^{40,102}$

Disinfection or sterilization of ultrasound transducer components is based on the function or use of each component. Considering that the biopsy needle penetrates sterile tissue for biopsy, it should be sterile. Ideally, the needle guide should be sterilized between patient uses. However, if this is not possible (ie, clinic does not have a sterilizer as biopsy needles are likely purchased as single-use sterile devices) then HLD after disassembly and cleaning is acceptable as it has contact with mucous membranes but not sterile tissue. The FDA alert $^{101}$ and a CDC article $^{40}$ recommends that the needle guide be sterilized as the biopsy needle contacts the needle guide before it penetrates sterile tissue. This recommendation is inconsistent with current recommendation for the disinfection of GI endoscopes. It is currently recommended that GI endoscopes be high-level disinfected minimally but that medical devices that pass through the endoscope and enter sterile tissue (eg, biopsy forceps) be sterilized. ${ }^{17,25}$ There is no recommendation that the lumen or channel through which they pass should also be sterilized. One possible explanation for the inconsistency in this FDA recommendation is that the GI endoscopes can only be high-level disinfected as there is no practical way to sterilize them, whereas the reusable needle guide for prostate probes can be sterilized (written communication, MJ Arduino, August 2006). Although a barrier sheath is used on the transducer assembly during the biopsy procedure, the sheath is compromised by the penetration of the needle. ${ }^{101}$ Although prostate probes and other endocavitary probes are often covered with a disposable sheath or condom, ${ }^{101}$ such covers do not adequately protect the probe from microbial contamination because of leakage (9\%), ${ }^{103}$ and thus, the use of a cover does not alter the requirement for HLD minimally. ${ }^{17}$ FDA specifies the use of a sterile barrier sheath in their recommendation for reprocessing reusable ultrasound transducer assemblies. ${ }^{101}$ It is appropriate to use a sterile barrier sheath when an ultrasound probe is entering a sterile body cavity, but when the probe is entering the rectum the need for a sterile barrier sheath is unclear.

All semicritical and critical medical devices must be thoroughly cleaned with enzymatic or nonenzymatic detergents before it is subjected to a HLD or sterilization process, respectively. Brushes should be used, when possible, to effectively clean the transducer assemblies, especially the lumens. One investigation shows that the needle guide and prostate probe can be effectively disinfected with glutaraldehyde, but the needle guide must be disassembled from the transducer assembly. ${ }^{20}$

The FDA issued a Public Health Notification in June 2006, because of follow-up to the Department of Veterans Affairs, Veterans Health Administration Patient Safety Alert related to a company's ultrasound transducer assemblies. During patient safety rounds, the lumen of a needle guide of an ultrasound transducer assembly was found to be soiled. The FDA guidance consisted of several steps (see http:// www.fda.gov/MedicalDevices/Safety/AlertsandNotices/PublicHealth Notifications/ucm062086.htm for complete method recommended by the FDA). We have evaluated the FDA steps and suggest some modifications. ${ }^{11}$ Do not reuse items labeled for single use (eg, singleuse biopsy needles, needle guides). Additional recommendations may be available in the operator's manuals or user guides. It is important that these recommendations be consistent with disinfection and sterilization guidelines/principles or that these recommendations have been validated by appropriate scientific studies. Do not use any disinfectant that can cause irreparable damage to the materials used to construct the probe. For example, if an alcohol rinse is not compatible with the probe, rinse with sterile water (not filtered water, or tap water), and do not rinse with alcohol. These recommendations could be adapted to all ultrasonic prostate probes to include those with an external needle guide attachment.

\section{TEE probes}

TEE probes are another semicritical device that has a potential for infection between sequential patients. Five outbreaks have been associated with TEE probes used in cardiovascular surgical operations. ${ }^{51,54-57}$ In 2 outbreaks, a defect in the probe was identified. ${ }^{54,55}$ Once the damaged TEE probes were removed from use, no additional cases were identified in the cardiac surgery patients. The defect presumably prevented exposure of the bacteria to the high-level disinfectant. To ensure proper HLD, health care facilities should ensure the probes are not damaged and comply with recommendations from professional organizations and the manufacturer. The basic principle for successful reprocessing of the probe involves: clean the probe shaft and probe tip (via immersion or wiped with a wipe moistened with detergent/enzymatic) to remove gross contamination (a second wipe is used to wipe nonimmersible parts higher up including the handle); inspect to ensure no structural damage; disinfect with a high-level disinfectant (distal tip and flexible shaft are immersed in the high-level disinfectant, wipe the higher portions with a compatible disinfectant); thoroughly rinse; and dry before storage. ${ }^{104}$ Protective sheaths are an additional physical barrier to infection and probe damage; however, they do not remove the possibility of infection as sheaths do not cover all of the TEE probes and the sheaths are subject to perforations. ${ }^{105}$ Strict adherence to manufacturers' instructions when using chemical disinfectants such as OPA for TEE probe reprocessing are required to avoid aerodigestive tract chemical injury. ${ }^{106}$ TEE probes require HLD regardless of whether a sheath is used. Many hospitals use a vapor control system that reduces exposure of staff to toxic vapors and damage to the instrument (eg, wall rack holder such as glutaraldehyde user station). Follow the manufacturer's instructions and/or professional organizational guidelines for soak times and cleaners.

\section{Infrared coagulation}

Infrared coagulation is a widely used method for treating hemorrhoids. The procedure involves applying infrared light to compress and seal hemorrhoid veins. The manufacturer of the device sells a sterile disposable sheath and states removing and soaking light guides between procedures is no longer required. The manufacturer also states that the light guide is damaged by immersion in a disinfectant as the light guide is not sealed at the end and the disinfectant gets between the quartz glass and the covering.

As mentioned, the CDC guideline recommends immersion for reprocessing endocavitary probes with covers because integrity of the cover is compromised. Because the light guide cannot be immersed, we investigated an alternative procedure. This procedure involved wiping the probe for 2 minutes with a 1:10 bleach $(5,000$ ppm) and after that was completed, wiping the probe with sterile water and letting the probe air dry. This procedure has been found effective in eliminating $\sim 7 \log _{10}$ reduction $\left(7.8 \times 10^{6}\right)$ of Mycobacterium terrae and is used at our hospital for decontamination of the sheathed device after use. ${ }^{107}$

\section{Laryngoscopes}

Laryngoscopes are a potential source of infection ${ }^{108}$ and have been associated with at least 2 outbreaks. ${ }^{43-45}$ Laryngoscopes are routinely used to view the vocal cords and larynx and for airway management. It typically consists of a blade that connects to a handle, which usually contains 2 batteries that powers the light source. Limited guidelines are available for reprocessing laryngoscope blades and handles and hospital practices vary. ${ }^{45,109,110}$ For example, some guidelines recommend and hospitals use low-level disinfection of the handle as it does not have direct contact with a mucous membrane, whereas others 
recommend that the handle be high-level disinfected to prevent disease transmission. Although blades have been linked to health care -associated infections, handles have not been directly linked to health care-associated infections. However, reports of contamination with blood ( $40 \%$ of the handles positive for occult blood) and potentially pathogenic microorganisms (86\% of the handles deemed "ready for patient use" positive including Staphylococcus aureus, Acinetobacter) suggest its potential ${ }^{45,111-113}$ and the blade and handle function together. For this reason, it is ideal that the blades and handles be high-level disinfected or sterilized, even if a protective barrier or sheath is used during the procedure. In 2007, the State of California required that both blades and handles be HLD or sterilized. At University of North Carolina Hospitals we were sterilizing the blades and handles (ie, blades via hydrogen peroxide gas plasma, handle [without batteries] by steam), but we have transitioned to sterile, disposable blades and handles. This practice saves time, eliminates the risk of cross contamination and reduces the likelihood on nonperforming equipment. A few specialty areas continue to sterilize the blade and handle. Per the Joint Commission, the laryngoscope blade and handle must be packaged in a way that prevents recontamination after processing. Examples of compliant storage include, but are not limited to, a peel pack poststerilization (long-term storage) or wrapping in a sterile towel (short-term storage).

Advances in video-technology have led to the development of video laryngoscopes such as the GlideScope (Verathon, Bothell, MA) and McGrath video laryngoscopes (Medtronic, Minneapolis, MN). These new intubation devices assist in difficult airway management. The manufacturer's IFU should be followed for reprocessing the reusable component of these scopes.

\section{Other channeled endoscopes (cystoscopes, ureteroscopes,} hysteroscopes)

In the United States, it is estimated that over 4 million cystoscopies are performed each year. Cystoscopy is a diagnostic procedure that uses an endoscope especially designed to examine the bladder, lower urinary tract, and prostate gland or is used to collect urine samples, perform biopsies, and remove small stones. A flexible or rigid scope can be used to carry out the procedure. Considering that the procedure involves a medical device in contact with the patient's mucous membranes, it is considered a semicritical device that must minimally be high-level disinfected. Failure to properly high-level disinfect or sterilize semicritical equipment can lead to contamination $^{114}$ and transmission of infection. ${ }^{46}$

A recent study demonstrated how important it is to perfuse the high-level disinfectant into the channel of cystoscopes and other channeled scopes (eg, hysteroscopes, ureteroscopes). This study demonstrated that disinfection (ie, a reduction in bacterial load of $>7$ $\log _{10}$ CFU) did not occur unless the channel was actively perfused with the glutaraldehyde. In fact, failure to perfuse the channel led to only minimal, if any, reduction in bacterial contamination. However, complete inactivation of $10^{8} \mathrm{CFU}$ of both vancomycin-resistant Enterococcus and CRE was achieved when the channel was actively perfused. It appears that no high-level disinfectant entered the channel unless it was actively perfused via a syringe, as the level of microbial contamination was not reduced by immersion. This occurs because the air pressure in the channel is stronger than the fluid pressure at the fluid-air interface. Recommendations are provided for cystoscope HLD and include actively perfusing the device while immersed in the high-level disinfectant. ${ }^{115}$

Cystoscopes have also been implicated as the source of infection to multiple patients when incorrect disinfection methods were identified. ${ }^{46}$ This may, in part, be related to the lack of awareness of recommendations specifically for disinfecting cystoscopes ${ }^{116}$ or failing to follow the manufacturer's instructions, which specify perfusing the lumen using a high-level disinfectant. Unfortunately, some cystoscope reprocessing recommendations published in the literature are incorrect. For example, authors have recommended complete immersion of the cystoscope into the high-level disinfectant but did not mention perfusion of the high-level disinfectant into the channel. ${ }^{46}$ We suggest following published recommendations ${ }^{11}$ and those of the American Urological Association ${ }^{116}$ until evidence-based guidelines have been published. Anaphylactic reactions have been reported in patients with bladder cancer who underwent repeated cystoscopy using scopes that were HLD with OPA, and thus, OPA is contraindicated in patients with a history of bladder cancer. ${ }^{116}$

\section{CURRENT ISSUES}

\section{Hydrogen peroxide mist system for probes}

An alternative procedure for disinfecting the endocavitary and surface probes is a hydrogen peroxide mist system, which uses $35 \%$ hydrogen peroxide at $56^{\circ} \mathrm{C}$ with the probe reaching no more than $40^{\circ} \mathrm{C}$ (ie, Trophon). In one study, the results demonstrated complete inactivation ( $>6$ - $\log _{10}$ reduction) of vancomycin-resistant Enterococcus and a CREKlebsiella pneumoniae strain in both the presence and absence of $5 \%$ fetal calf serum (FCS). The Trophon EPR system (Nanosonics, Indianapolis, IN) showed good, but not complete, inactivation of $M$ terrae (5.2$\log _{10}$ reduction for $M$ terrae with FCS; $4.6-\log _{10}$ reduction for $M$ terrae without FCS) and $C$ difficile spores (5.1- $\log _{10}$ reduction for $C$ difficile spores with FCS; $6.2-\log _{10}$ reduction for $C$ difficile spores without FCS). ${ }^{117}$ Other data have demonstrated the activity of Trophon to inactivate $\mathrm{HPV}^{118}$ and other pathogens (eg, bacteria, mycobacteria, viruses) including a $>6-\log _{10}$ reduction of $M$ terrae and $C$ difficile spores in carrier tests and a $>6-\log _{10}$ reduction in $M$ terrae on inoculated ultrasound probes. ${ }^{119}$ These results differ slightly from those presented earlier, presumably because of the differences in testing methodology. In our study, only the probe devices were inoculated (carriers of different materials were not tested) and for recovery of bacteria on the probe, the probes were immersed in media (not swabbed, which would likely result in lower recovery). ${ }^{117}$ The Trophon system processes the portion of the probe that has mucous membrane contact but also the handle of an endocavitary probe, which may be contaminated, and it is an alternative to high-level chemical disinfection for ultrasound probes.

\section{Storage of semicritical items}

In 2011, the Joint Commission recommended that laryngoscope blades be packaged in a way that prevents recontamination. Examples of compliant storage include, but are not limited to, a peel pouch or a closed plastic bag. Examples of noncompliant storage would include unwrapped blades in an anesthesia drawer as well as an unwrapped blade on top of or within a code cart. The packaging not only prevents recontamination but also distinguishes a processed from a nonprocessed semicritical item such as a speculum, laryngoscope blade, or endoscope. The use of a tagging system that separates processed from nonprocessed items minimizes the use of a semicritical item that has not been reprocessed and prevents patient exposures to a nonreprocessed semicritical item. ${ }^{6}$ This could involve a tag (eg, green tag = patient ready, red tag = requires reprocessing) for GI endoscopes or a plastic sheath or plastic-paper peel pouch (eg, endocavitary probes). Ideally, hospitals and ambulatory care facilities (as appropriate) ${ }^{24}$ should develop a strategy (eg, tagging, storage covers for patient-ready devices) that prevents patient exposures to contaminated devices.

\section{HPV}

HPV is an extremely common sexually-acquired infection and is the most important cause of cervical cancer. An article in 2014 
demonstrated that the FDA-cleared high-level disinfectants (ie, glutaraldehyde, OPA) tested did not inactivate the HPV, a nonenveloped virus. ${ }^{97}$ These findings are inconsistent with many articles in the peerreviewed literature that demonstrates that high-level disinfectants such as OPA and glutaraldehyde inactivate nonenveloped viruses such as hepatitis A virus, polio, adenovirus, norovirus, et cetera. ${ }^{17}$ Because the HLD are commonly used to disinfect endocavitary probes (eg, vaginal probes, rectal probes), there is an urgency to corroborate these data. In a conversation with $\mathrm{CDC}$ staff regarding this issue, it was determined hospitals should continue to use the FDA-cleared high-level disinfectants consistent with the manufacturers' instructions until the data can be corroborated. Data have demonstrated the activity of a hydrogen peroxide mist device ${ }^{118}$ as well as a UV-C unit ${ }^{120}$ to inactivate the HPV. To reduce the risk of transmission of HPV via transvaginal ultrasound, Combs and Fishman ${ }^{121}$ recommended disinfection of the transvaginal probe with the hydrogen peroxide mist device and covering them with a condoms during examinations. In October 2018, an abstract by Ozbun et al was presented at the $32^{\text {nd }}$ International Papillomavirus Conference in Australia, which demonstrated that HPV was inactivated by a variety of disinfectants including OPA.

\section{Do not reuse single-use devices}

The Department of Justice and the FDA have joined forces in prosecuting health care providers that reuse single-use devices. For example, a physician was criminally prosecuted for reusing needle guides meant for single use during prostate procedures. These prosecutions are based on conspiracy to commit adulteration and Medicare fraud. Third party reprocessing is allowed by the FDA when the reprocessor is considered the device manufacturer as defined under 21 CFR Part 820.

\section{CONCLUSIONS}

Strict adherence to current guidelines are required for semicritical items, as more outbreaks have been linked to inadequately cleaned or disinfected semicritical items such as endoscopes undergoing HLD than any other reusable medical device.

\section{References}

1. Centers for Disease Control and Prevention. National hospital discharge survey: 2010 table, procedures by selected patient characteristics-number by procedure category and age. 2010.

2. Peery AF, Dellon ES, Lund JC, Crockett SD, McGowan CE, Buisiewicz WJ, et al. Burden of gastrointestinal disease in the United States: 2012 update. Gastroenterol 2012;143:1179-87.

3. Epstein L, Hunter JC, Arwady MA, et al. New Delhi metallo-beta-lactamase-producing carbapenem-resistant Escherichia coli associated with exposure to duodenoscopes. JAMA 2014;312:1447-55.

4. Wendorf KA, Kay M, Baliga C, Weissman SJ, Gluck M, Verma P, et al. Endoscopic retrograde cholangiopancreatography-associated AmpC Escherichia coli outbreak. Infect Control Hosp Epidemiol 2015;36:634-42.

5. Ofstead CL, Wetzler HP, Snyder AK, Horton RA. Endoscope reprocessing methods: a prospective study on the impact of human factors and automation. Gastroenterol Nurs 2010;33:304-11.

6. Rutala WA, Weber DJ. How to assess risk of disease transmission to patients when there is a failure to follow recommended disinfection and sterilization guidelines. Infect Control Hosp Epidemiol 2007;28:146-55.

7. Kovaleva J, Peters FT, van der Mei HC, Degener JE. Transmission of infection by flexible gastrointestinal endoscopy and bronchoscopy. Clin Microbiol Rev 2013;26:231-54

8. Murray P. Preventable tragedies: superbugs and how ineffective monitoring of medical device safety fails patients. Available from: https://www.help.senate. gov/imo/media/doc/Duodenoscope\%20Investigation\%20FINAL\%20Report.pdf. United States Senate Minority Report; 2016. Accessed February 27, 2019.

9. Centers for Disease Control and Prevention. Immediate need for healthcare facilities to review procedures for cleaning, disinfecting, and sterilizing reusable medical devices. Available from: http://emergency.cdc.gov/han/han00382.asp; 2015. Accessed February 27, 2019.

10. Rutala WA, Weber DJ. New developments in reprocessing semicritical items. Am J Infect Control 2013;41:60-6.
11. Rutala WA, Weber DJ. Reprocessing semicritical items: current issues and new technologies. Am J Infect Control 2016;44:e53-62.

12. Spaulding EH. Chemical disinfection of medical and surgical materials. In: Lawrence C, Block SS, editors. Disinfection, sterilization, and preservation. Philadelphia (PA): Lea \& Febiger; 1968. p. 517-31.

13. Rutala WA, Weber DJ. Disinfection, sterilization and control of hospital waste. In: Bennett JE, Dolan R, Blaser MJ, editors. Principles and practice of infectious diseases. Philadelphia (PA): Elsevier Saunders; 2015. p. 3294-309.

14. Rutala WA, Weber DJ. Disinfection and sterilization: an overview. Am J Infect Control 2013;41:2-5

15. Rutala WA, Weber DJ. Cleaning, disinfection and sterilization. In: Grota P, editor. 4th ed. APIC text of infection control and epidemiology, 31, Washington (DC): Association for Professionals in Infection Control and Epidemiology; 2014:1-15.

16. Rutala WA, Weber DJ. Disinfection, sterilization, and control of hospital waste. In: Bennett JE, Dolan R, Blaser MJ, editors. Principles and Practices of Infectious Diseases. Philadelphia (PA): Elsevier; In press.

17. Rutala WA, Weber DJ. Healthcare Practices Advisory Committee. Centers for Disease Control and Prevention. Guideline for disinfection and sterilization in healthcare facilities. 2008. Available from: http://www.cdc.gov/ncidod/dhqp/ pdf/guidelines/Disinfection_Nov_2008.pdf. Accessed February 27, 2019.

18. Joint Commission. High-level disinfection (HLD) and sterilization boosterpak. Chicago (IL): Joint Commission.

19. McDonnell G, Burke P. Disinfection: is it time to reconsider Spaulding? J Hosp Infect 2011;78:163-70.

20. Rutala WA, Gergen MF, Weber DJ. Disinfection of a probe used in ultrasoundguided prostate biopsy. Infect Control Hosp Epidemiol 2007;28:916-9.

21. Food and Drug Administration. FDA-cleared sterilants and high level disinfectants with general claims for processing reusable medical and dental devices, March 2015. Available from: http://wwwfdagov/MedicalDevices/ DeviceRegulationandGuidance/ReprocessingofReusableMedicalDevices/ ucm437347htm. Accessed February 27, 2019.

22. Ragan A, Cote SL, Huang JT. Disinfection of the Goldman applanation tonometer: a systematic review. Can J Ophthalmol 2018;53:252-9.

23. Rutala WA, Weber DJ. ERCP scopes: what can we do to prevent infections? Infect Control Hosp Epidemiol 2015;36:643-8

24. Bringhurst J. Special problems associated with reprocessing instruments in outpatient care facilities. Am J Infect Control 2016;44:e63-7.

25. Petersen B, Cohen J, Hambrick RD, Buttar N, Greenwald DA, Buscaglia JM, et al. Multisociety guideline on reprocessing flexible gastrointestinal endoscopes, 2016. Gastrointest Endosc 2017;85:282-94.

26. Gerding DN, Peterson LR, Vennes JA. Cleaning and disinfection of fiberoptic endoscopes: evaluation of glutaraldehyde exposure time and forced-air drying. Gastroenterology 1982:83:613-8.

27. Kovaleva J, Degener JE, van der Mei HC. Mimicking disinfection and drying of biofilms in contaminated endoscopes. J Hosp Infect 2010;76:345-50.

28. Weber DJ, Rutala WA. Environmental issues and nosocomial infections. In: Wenzel RP, editor. Prevention and control of nosocomial infections, 3rd ed. Baltimore (MD): Williams and Wilkins; 1997. p. 491-514.

29. Tosh PK, Disbot M, Duffy JM, Boom ML, Heseltine G, Srinivasan A, et al. Outbreak of Pseudomonas aeruginosa surgical site infections after arthroscopic procedures: Texas, 2009. Infect Control Hosp Epidemiol 2011;32:1179-86.

30. Roberts CG. Studies on the bioburden on medical devices and the importance of cleaning. In: Rutala WA, editor. Disinfection, sterilization and antisepsis: principles and practices in healthcare facilities. Washington (DC): Association for Professionals in Infection Control and Epidemiology; 2000. p. 63-9.

31. Alfa MJ, Degagne P, Olson N. Worst-case soiling levels for patient-used flexible endoscopes before and after cleaning. Am J Infect Control 1999;27:392-401

32. Rutala WA, Weber DJ. FDA labeling requirements for disinfection of endoscopes: a counterpoint. Infect Control Hosp Epidemiol 1995;16:231-5.

33. Leroy S. Infectious risk of endovaginal and transrectal ultrasonography: systematic review and meta-analysis. J Hosp Infect 2013;83:99-106.

34. Birnie GG, Quigley EM, Clements GB, Follet EA, Watkinson G. Endoscopic transmission of hepatitis B virus. Gut 1983:24:171-4

35. Bronowicki JP, Venard V, Botte C, Monhoven N, Gastin I, Chone L, et al. Patient-topatient transmission of hepatitis C virus during colonoscopy. N Engl J Med 1997;337:237-40.

36. Le Pogam S, Gondeau A, Bacq Y. Nosocomial transmission of hepatitis C virus. Ann Intern Med 1999;131:794.

37. Williams IT, Perz JF, Bell BP. Viral hepatitis transmission in ambulatory health care settings. Clin Infect Dis 2004;38:1592-8.

38. Morris J, Duckworth GJ, Ridgway GL. Gastrointestinal endoscopy decontamination failure and the risk of transmission of blood-borne viruses: a review. J Hosp Infect 2006;63:1-13.

39. Rutala WA, Kanamori H, Sickbert-Bennett EE, Weber DJ. What's new in reprocessing endoscopes: are we going to ensure "the needs of the patient come first" by shifting from disinfection to sterilization? Am J Infect Control 2019;47(Suppl): A62-6.

40. Gillespie JL, Arnold KE, Noble-Wang J, Jensen B, Arduino M, Hageman J, et al. Outbreak of Pseudomonas aeruginosa infections after transrectal ultrasound-guided prostate biopsy. Urology 2007;69:912-4.

41. Viney KA, Kehoe PJ, Doyle B, Sheppeard V, Roberts-Witteveen AR, Semirli H, et al. An outbreak of epidemic keratoconjunctivitis in a regional ophthalmology clinic in New South Wales. Epidemiol Infect 2007;136:1197-206. 
42. Montessori V, Scharf S, Holland S, Werker DH, Roberts FJ, Bryce E. Epidemic keratoconjunctivitis outbreak at a tertiary referral eye care clinic. Am J Infect Control 1998;26:399-405.

43. Cullen MM, Trail A, Robinson M, Keaney M, Chadwick PR. Serratia marcescens outbreak in a neonatal intensive care unit prompting review of decontamination of laryngoscopes. J Hosp Infect 2005;59:68-70.

44. Associated Press. LA hospital cited for deadly bacterial outbreak. Associated Press. Available from: http://www.nbcnews.com/id/16789125/ns/health-health_care/t/ la-hospital-cited-deadly-bacterial-outbreak/\#.XEDmNPZFzMo; 2007. Accessed February 27, 2019.

45. Muscarella LF. Reassessment of the risk of healthcare-acquired infection during rigid laryngoscopy. J Hosp Infect 2008;68:101-7.

46. Wendelboe AM, Baumbach J, Blossom DB, Frank P, Srinivasan A, Sewell CM. Outbreak of cystoscopy related infections with Pseudomonas aeurginosa: New Mexico, 2007. J Urology 2008; 180:588-92.

47. Koo VS, O'Neill P, Elves A. Multidrug-resistant NDM-1 Klebsiella outbreak and infection control in endoscopic urology. BJU Int 2012;110:E922-6.

48. Jimeno A, Alcalde MM, Ortiz M, Rodríguez A, Alcaraz B, Vera F. Outbreak of urinary tract infections by Salmonella spp. after cystoscopic manipulation. Actas Urol Esp 2016;40:646-9.

49. OYong K, Coelho L, Bancroft E, Terashita D. Health care-associated infection outbreak investigations in outpatient settings, Los Angeles County, California, USA, 2000-2012. Emerg Infect Dis 2015;21:1317-21.

50. Chang CL, Su LH, Lu CM, Tai FT, Huang YC, Chang KK. Outbreak of ertapenemresistant Enterobacter cloacae urinary tract infections due to a contaminated ureteroscope. J Hosp Infect 2013;85:118-24.

51. Strand CL, Bryant JK, Morgan JW, Foster JG, McDonald HP, Morganstern SL. Nosocomial Pseudomonas aeruginosa urinary tract infections. JAMA 1982;248: 1615-8.

52. Echols RM, Palmer DL, King RM, Long GW. Multidrug-resistant Serratia marcescens bacteriuria related to urologic instrumentation. South Med J 1984:77:173-7.

53. Climo MW, Pastor A, Wong ES. An outbreak of Pseudomonas aeruginosa related to contaminated urodynamic equipment. Infect Control Hosp Epidemiol 1997; 18:509-10.

54. Seki M, Machida N, Yamagishi Y, Yoshida H, Tomono K. Nosocomial outbreak of multidrug-resistant Pseudomonas aeruginosa caused by damaged transesophageal echocardiogram probe used in cardiovascular surgical operations. J Infect Chemother 2013;19:677-81.

55. Bancroft EA, English L, Terashita D, Yasuda L. Outbreak of Escherichia coli infections associated with a contaminated transesophageal echocardiography probe. Infect Control Hosp Epidemiol 2013:34:1121-3.

56. Kanemitsu K, Endo S, Oda K, Saito K, Kunishima H, Hatta M, et al. An increased incidence of Enterobacter cloacae in a cardiovascular ward. J Hosp Infect 2007;66:130-4.

57. Levy PY, Teysseire N, Etienne J, Raoult D. A nosocomial outbreak of Legionella pneumophila caused by contaminated transesophageal echocardiography probes. Infect Control Hosp Epidemiol 2003;24:619-22.

58. Centers for Disease Control and Prevention. Pseudomonas aeruginosa respiratory tract infections associated with contaminated ultrasound gel used for transesophageal echocardiography-Michigan, December 2011-January 2012. MMWR Morb Mortal Wkly Rep 2012;61:262-4

59. Willmore J, Ellis E, Etches V, Labrecque L, Osiowy C, Andonov A, et al. Public health response to a large-scale endoscopy infection control lapse in a nonhospital clinic. Can J Infect Dis Med Microbiol 2015;26:77-84.

60. Holodniy M, Oda G, Schirmer PL, Lucero CA, Khudyakov YE, Xia G, et al. Results from a large-scale epidemiologic look-back investigation of improperly reprocessed endoscopy equipment. Infect Control Hosp Epidemiol 2012;33:649-56.

61. Rutala WA, Weber DJ. Reprocessing semicritical items: outbreaks and current issues. Am J Infect Control 2019;47(Suppl):A79-89.

62. Food and Drug Administration. Brief summary of the gastroenterology and urology devices panel meeting. 2015. Available from: https://www.hayesinc.com/hayes/ resource-center/news-service/HNS-20150420-49/. Accessed March 1, 2019.

63. Pajkos A, Vickery K, Cossart Y. Is biofilm accumulation on endoscope tubing a contributor to the failure of cleaning and decontamination. J Hosp Infect 2004;58:224.

64. Roberts CG. The role of biofilms in reprocessing medical devices. In: Rutala WA, editor. Disinfection, sterilization and antisepsis: principles, practices, current issues, new research, and new technologies. Washington (DC): Association for Professionals in Infection Control and Epidemiology; 2010. p. 223-9.

65. Neves MS, daSilva MG, Ventura GM, Cortes PB, Duarte RS, deSouza HS. Effectiveness of current disinfection procedures against biofilm on contaminated GI endoscopes. Gastrointest Endosc 2015.

66. Ren-Pei W, Hui-Jun X, Ke Q, Dong W, Xing N, Zhao-Shen L. Correlation between the growth of bacterial biofilm in flexible endoscopes and endoscope reprocessing methods. Am J Infect Control 2014;42:1203-6.

67. Agrawal D, Muscarella LF. Delayed reprocessing of endoscopes. Gastrointest Endosc 2011:73:853-4.

68. Sowerby LJ, Rudmik L. The cost of being clean: a cost analysis of nasopharyngoscope reprocessing techniques. Laryngoscope 2018;128:64-71.

69. Collins WO. A review of reprocessing techniques of flexible nasopharyngoscopes. Otolaryngol Head Neck Surg 2009;141:307-10.

70. Cavaliere M, Iemma M. Guidelines for reprocessing nonlumened heat-sensitive ear/nose/throat endoscopes. Laryngoscope 2012;122:1708-18.
71. Alvarado CJ, Anderson AG, Maki DG. Microbiologic assessment of disposable sterile endoscopic sheaths to replace high-level disinfection in reprocessing: a prospective clinical trial with nasopharyngoscope. Am J Infect Control 2009;37:408-13.

72. Elackattu A, Zoccoli M, Spiegel JH, Grundfast KM. A comparison of two methods for preventing cross-contamination when using flexible fiberoptic endoscopes in an otolaryngology clinic: disposable sterile sheaths versus immersion in germicidal liquid. Laryngoscope 2010:120:2410-6.

73. Durand ML, Weber DJ, Rutala WA. Healthcare-associated eye infections. In: Mayhall CG, editor. Hospital epidemiology and infection control. Philadelphia (PA): Wolters Kluwer; 2012. p. 352-64

74. Centers for Disease Control. Recommendations for preventing possible transmission of human T-lymphotropic virus type III/lymphadenopathy-associated virus from tears. MMWR Morb Mortal Wkly Rep 1985;34:533-4.

75. Rutala WA, Peacock JE, Gergen MF, Sobsey MD, Weber DJ. Efficacy of hospital germicides against adenovirus 8, a common cause of epidemic keratoconjunctivitis in health care facilities. Antimicrob Agents Chemother 2006;50: 1419-24.

76. Tyler R, Ayliffe GA, Bradley C. Virucidal activity of disinfectants: studies with the poliovirus. J Hosp Infect 1990;15:164-6.

77. Sattar SA, Springthorpe VS, Karim Y, Loro P. Chemical disinfection of non-porous inanimate surfaces experimentally contaminated with four human pathogenic viruses. Epidemiol Infect 1989;102:493-505.

78. Chronister CL. Structural damage to Schiotz tonometers after disinfection with solutions. Optom Vis Sci 1997;74:164-6.

79. Koo D, Bouvier B, Wesley M, Courtright P, Reingold A. Epidemic keratoconjunctivitis in a university medical center ophthalmology clinic; need for re-evaluation of the design and disinfection of instruments. Infect Control Hosp Epidemiol 1989; 10:547-52

80. Jernigan JA, Lowry BS, Hayden FG, Kyger SA, Conway BP, Groschel DH, et al. Adenovirus type 8 epidemic keratoconjunctivitis in an eye clinic: risk factors and control. J Infect Dis 1993;167:1307-13.

81. Chang DF, Mamalis N. Ophthalmic instrument cleaning and sterilization task force. Guidelines for the cleaning and sterilization of intraocular surgical instruments. J Cataract Refract Surg 2018;44:765-73.

82. Milki AA, Fisch JD. Vaginal ultrasound probe cover leakage: implications for patient care. Fertil Steril 1998;69:409-11.

83. Storment JM, Monga M, Blanco JD. Ineffectiveness of latex condoms in preventing contamination of the transvaginal ultrasound transducer head. South Med J 1997;90:206-8.

84. Fritz S, Hust $\mathrm{MH}$, Ochs C, Gratwohl I, Staiger M, Braun B. Use of a latex cover sheath for transesophageal echocardiography (TEE) instead of regular disinfection of the echoscope? Clin Cardiol 1993;16:737-40.

85. Hignett M, Claman P. High rates of perforation are found in endovaginal ultrasound probe covers before and after oocyte retrieval for in vitro fertilizationembryo transfer. J Assist Reprod Genet 1995;12:606-9.

86. Kac G, Podglajen I, Si-Mohamed A, Rodi A, Grataloup C, Meyer G. Evaluation of ultraviolet $\mathrm{C}$ for disinfection of endocavitary ultrasound transducers persistently contaminated despite probe covers. Infect Control Hosp Epidemiol 2010;31:165-70.

87. Abramowicz JS, Evans DH, Fowlkes JB, Marsal K, TerHaar G. World Federation for Ultrasound in Medicine and Biology. Guidelines for cleaning transvaginal ultrasound transducers between patients. Ultrasound in Med Biol 2017;43: 1076-9.

88. Amis S, Ruddy M, Kibbler CC, Economides DL, MacLean AB. Assessment of condoms as probe covers for transvaginal sonography. J Clin Ultrasound 2000;28:295-8.

89. Rooks VJ, Yancey MK, Elg SA, Brueske L. Comparison of probe sheaths for endovaginal sonography. Obstet Gynecol 1996;87:27-9.

90. Odwin CS, Fleischer AC, Kepple DM, Chiang DT. Probe covers and disinfectants for transvaginal transducers. J Diagn Med Sonogr 1990;6:130-5.

91. Benson WG. Exposure to glutaraldehyde. J Soc Occup Med 1984;34:63-4.

92. Kac G, Gueneret M, Rodi A, Bergel E, Grataloup C, Denarie N, et al. Evaluation of a new disinfection procedure for ultrasound probes using ultraviolet light. J Hosp Infect 2007;65:163-8.

93. Fowler C, McCracken D. US probes: risk of cross infection and ways to reduce it-comparison of cleaning methods. Radiology 1999;213:299-300.

94. Muradali D, Gold WL, Phillips A, Wilson S. Can ultrasound probes and coupling gel be a source of nosocomial infection in patients undergoing sonography? An in vivo and in vitro study. AJR Am J Roentgenol 1995;164:1521-4.

95. Casalegno JS, Le Bail Carval K, Eibach D, Valdeyron ML, Lamblin G, Jacquemoud H, et al. High risk HPV contamination of endocavity vaginal ultrasound probes: an underestimated route of nosocomial infection? PLoS One 2012:7:e48137.

96. M’Zali F, Bounizra C, Leroy S, Mekki Y, Quentin-Noury C, Kann M. Persistence of microbial contamination on transvaginal ultrasound probes despite low-level disinfection procedure. PLoS One 2014:9:e93368.

97. Meyers J, Ryndock E, Conway MJ, Meyers C, Robison R. Susceptibility of high-risk human papillomavirus type 16 to clinical disinfectants. J Antimicrob Chemother 2014:69:1546-50

98. Carrico RM, Furmanek S, English C. Ultrasound probe use and reprocessing: results from a national survey among US infection preventionists.. Am J Infect Control 2018;46:913-20.

99. Thompson J, Garrett JH Jr. Guidance document: transducer disinfection for assessment and insertion of peripheral and central catheters. Association for Vascular Access 2018: 1-13. 
100. American Institute of Ultrasound in Medicine. Guidelines for cleaning and preparing external and internal ultrasound probes between patients, safe handling, and use of ultrasound couplin gel. 2018.

101. Public Health Notification. Reprocessing of reusable ultrasound transducer assemblies used for biopsy procedures, 2006. Available from: http://www.fda. gov/MedicalDevices/Safety/AlertsandNotices/PublicHealthNotification/ ucm062086.htm. Accessed February 27, 2019.

102. Lessa F, Tak S, Devader SR, Goswami R, Anderson M, Williams I, et al. Risk of infections associated with improperly reprocessed transrectal ultrasoundguided prostate biopsy equipment. Infect Control Hosp Epidemiol 2008;29:289-93.

103. Masood J, Voulgaris S, Awogu O, Younis C, Ball AJ, Carr TW. Condom perforation during transrectal ultrasound guided (TRUS) prostate biopsies: a potential infection risk. Int Urol Nephrol 2007;39:1121-4.

104. Anonymous. Cleaning, disinfecting, and sterilizing TEE transducers. Available from: http://www.healthcare.philips.com/main/products/ultrasound/transducers/ transducer_care/cleaning_and_disinfecting/tee_transducers.wpd. Accessed February 27, 2019.

105. Kanagala P, Bradley C, Hoffman P, Steeds RP. Guidelines for transesophageal echocardiographic probe cleaning and disinfection from the British Society of Echocardiography. Eur J Echocardiogr 2011;12:117-23.

106. Venticinque SG, Kashyap VS, O'Connell RJ. Chemical burn injury secondary to intraoperative transesophageal echocardiography. Anesth Analg 2003;97: 1260-1.

107. Rutala WA, Gergen MF, Weber DJ. Disinfection of an infrared coagulation device used to treat hemorrhoids. Am J Infect Control 2012;40:78-9.

108. Negri de Sousa AC, Levy CE, Freitas MI. Laryngoscope blades and handles as sources of cross-infection: an integrative review. J Hosp Infect 2013;83: 269-75.

109. Muscarella LF. Prevention of disease transmission during flexible laryngoscopy. Am J Infect Control 2007;35:536-44
110. Muscarella LF. Recommendations to resolve inconsistent guidelines for the reprocessing of sheathed and unsheathed rigid laryngoscopes. Infect Control Hosp Epidemiol 2007;28:504-7.

111. Call TR, Auerbach FJ, Riddell SW, Kiska DL, Thongrod SC, Tham SW, et al. Nosocomial contamination of laryngoscope handles: challenging current guidelines. Anesth Analg 2009;109:479-83.

112. Williams D, Dingley J, Jones C, Berry N. Contamination of laryngoscope handles. J Hosp Infect 2010;74:123-8.

113. Phillips RA, Monaghan WP. Incidence of visible and occult blood on laryngoscope blades and handles. AANA J 1997;65:241-6.

114. Ofstead CL, Heymann OL, Quick MR, Johnson EA, Eiland JE, Wetzler HP. The effectiveness of sterilization for flexible ureteroscopes: a real-world study. Am J Infect Control 2017;45:888-95.

115. Rutala WA, Gergen MF, Bringhurst J, Weber DJ. Effective high-level disinfection of cystoscopes: is perfusion of channels required? Infect Control Hosp Epidemiol 2016;37:228-31.

116. Clemens JQ, Dowling R, Foley F, Goldman HB, Gonzalez CM, Tessier C, et al. Joint AUA/SUNA white paper on reprocessing of flexible cystoscopes. J Urol 2010; $184: 2241-5$

117. Rutala WA, Gergen MF, Sickbert-Bennett EE. Effectiveness of a hydrogen peroxide mist (Trophon ${ }^{\circledR}$ ) system in inactivating healthcare pathogens on surface and endocavitary probes. Infect Control Hosp Epidemiol 2016;37:613-4.

118. Ryndock E, Robison R, Meyers C. Susceptibility of HPV 16 and 18 to high-level disinfectants indicated for semi-critical ultrasound probes. J Med Virol 2016;88:1076-80

119. Vickery K, Gorgis VZ, Burdach J, Patel D. Evaluation of an automated high-level disinfection technology for ultrasound transducers. J Infect Public Health 2014; 7:153-60.

120. Meyers C, Milici J, Robison R. UVC radiation as an effective disinfectant method to inactivate human papillomavirus. PLOS ONE 2017.

121. Combs CA, Fishman A. A proposal to reduce the risk of transmission of human papilloma virus via transvaginal ultrasound. Am J Obstet Gynecol 2016;215:63-7. 